\title{
Słowo dziekana Wydziału Prawa Kanonicznego Uniwersytetu Papieskiego Jana Pawła II w Krakowie podczas prezentacji Praktycznego komentarza do listu apostolskiego motu proprio „Mitis Iudex Dominus Iesus” papieża Franciszka DOI: http://dx.doi.org/10.15633/acan.1834
}

Dnia 10 grudnia 2015 o godz. 12, w auli budynku Uniwersytetu Papieskiego Jana Pawła II w Krakowie przy ulicy Bernardyńskiej 3 odbyła się prezentacja przygotowanego przez pracowników Wydziału Prawa Kanonicznego UPJPII - pod redakcją naukową o. dr. hab. Piotra Skoniecznego op - komentarza dotyczącego reformy kanonicznego procesu małżeńskiego wydanego przez Wydawnictwo Diecezji Tarnowskiej BIBLos: Praktyczny komentarz do Listu apostolskiego motu proprio „Mitis Iudex Dominus Iesus” papieża Franciszka, Uniwersytet Papieski Jana Pawła II w Krakowie, Wydział Prawa Kanonicznego, Tarnów 2015.

Program prezentacji obejmował: wspólną modlitwę „Anioł Pański”, powitanie oraz słowo wprowadzające ks. prof. dr. hab. Tomasza Rozkruta - dziekana WPK UPJPII w Krakowie, wystąpienie o. dr. hab. Piotra Skoniecznego op - redaktora naukowego komentarza, dyskusję oraz raut.

Szanowni Państwo, w Rzymie, u Świętego Piotra, w uroczystość Wniebowzięcia Najświętszej Maryi Panny, dnia 15 sierpnia 2015 roku, w trzecim roku swojego pontyfikatu - papież Franciszek - podpisał List apostolski motu proprio Mitis Iudex Dominus Iesus, reformujący kanony kodeksu prawa kanonicznego dotyczące spraw o orzeczenie nieważności małżeństwa oraz List apostolski motu proprio Mitis et misericors Iesus, reformujący kanony kodeksu kanonów Kościołów wschodnich dotyczące spraw o orzeczenie nieważności małżeństwa. Postanowił również, aby to wszystko, co starannie rozważył oraz ogłosił, obowiązywało w Kościele powszechnym z dniem 8 grudnia 2015 roku.

Możemy zatem dzisiaj, 10 grudnia 2015 roku, śmiało powiedzieć, że reforma franciszkańska kanonicznego procesu dotyczącego orzekania w przedmiocie nieważności małżeństwa ma już formalne zastosowanie w praktyce sądowej Kościoła, a sam papież Franciszek gorliwe stosowanie nowego procesu małżeńskiego powierzył wstawiennictwu chwalebnej i błogosławionej Dziewicy Maryi, Matki miłosierdzia, oraz świętym apostołom Piotrowi i Pawłowi. 
Decyzja, a właściwie reforma papieża Franciszka, spowodowała wiele różnych inicjatyw naukowych, odbyło się już wiele sympozjów na jej temat, tak w samym Rzymie, jak i poza nim; również w Polsce miały miejsce na przestrzeni ostatnich miesięcy ważne oraz interesujące wydarzenia naukowe.

Dzisiaj spotykamy się w królewskim oraz papieskim Krakowie, u podnóża wzgórza wawelskiego, na prezentacji Praktycznego komentarza do listu apostolskiego motu proprio „Mitis Iudex Dominus Iesus” papieża Franciszka, który - pod redakcją naukową o. dr. hab. Piotra Skoniecznego op - został przygotowany przez pracowników Wydziału Prawa Kanonicznego Uniwersytetu Papieskiego Jana Pawła II w Krakowie.

Publikacja została wydana przez Bı BLOs - Wydawnictwo Diecezji Tarnowskiej.

Witam bardzo serdecznie wszystkich przybyłych na dzisiejszą prezentację naszej publikacji. Witam zaproszonych gości, a przede wszystkim redaktora oraz współautorów prezentowanego komentarza.

Szczególne podziękowanie kieruję do JE ks. kard. Stanisława Dziwisza, wielkiego kanclerza naszego Uniwersytetu, który nie tylko był bardzo przychylny inicjatywie Wydziału Prawa Kanonicznego, ale napisał także znaczące słowo wprowadzenia przedmowę do naszego komentarza, w którym czytamy: „nowe motu proprio papieża Franciszka Mitis Iudex Dominus Iesus, które reformuje procesy małżeńskie, jest podjęciem tego, co zapoczątkował w swoim duszpasterstwie św. Jan Paweł II. Jestem przekonany, że nie byłoby tak duszpasterskich norm, jak te, które opublikował papież Franciszek, gdyby nie wielkie dzieło na tym polu małżeństwa i rodziny Papieża z Polski. Dlatego z tym większą radością - jako pasterz Kościoła w Krakowie - przyjąłem inicjatywę Wydziału Prawa Kanonicznego Uniwersytetu Papieskiego Jana Pawła II skomentowania na sposób praktyczny nowej ustawy. Prawo kanoniczne bowiem ma być narzędziem, prowadzącym wiernych do zbawienia, także poprzez trudne procesy małżeńskie, mające ustalić prawdę o sakramencie” (S. Dziwisz, Przedmowa, [w:] „Praktyczny komentarz do Listu apostolskiego motu proprio Mitis Iudex Dominus Iesus papieża Franciszka”, red. P. Skonieczny, Tarnów 2015, s. 6).

Współczesna, dzisiejsza reforma kanonicznego procesu małżeńskiego, to niewątpliwie wydarzenie historyczne, związane w szczególności z Synodem Biskupów 2014, która wymaga rzetelnego oraz dokładnego wprowadzenia w życie, a szczególna odpowiedzialność w tym zakresie będzie spoczywała na biskupach diecezjalnych, metropolitach oraz na konferencjach biskupów. Taka jest bowiem wola samego 
papieża Franciszka, który we wstępie do motu proprio Mitis Iudex Dominus Iesus napisał: „Zatem troska o zbawienie dusz, która - zarówno dzisiaj, tak jak w przeszłości - pozostaje najwyższym celem instytucji, ustaw i prawa, skłania Biskupa Rzymu do przedstawienia biskupom niniejszego aktu reformy. Uczestniczą bowiem oni wraz z nim w misji Kościoła, polegającej na ochronie jedności w wierze i w dyscyplinie dotyczącej małżeństwa, które jest podstawą i źródłem pochodzenia rodziny chrześcijańskiej” (papież Franciszek, List apostolski motu proprio „Mitis Iudex Dominus Iesus", reformujący kanony Kodeksu Prawa Kanonicznego dotyczące spraw o orzeczenie nieważności matżeństwa. List apostolski motu proprio „Mitis et misericors Iesus", reformujący kanony Kodeksu Kanonów Kościołów Wschodnich dotyczące spraw o orzeczenie nieważności małżeństwa [tekst łacińsko-polski], BIBLOS 2015, s. 9).

Z historycznego punktu widzenia trzeba powiedzieć, że reforma papieża Franciszka to kolejna reforma procesu małżeńskiego. Stąd też z przeszłości dobrze będzie przywołać np. decyzję papieża Klemensa V z roku 13o6, który wprowadził proces skrócony, nazywany także od imienia papieża procesem klementyńskim, czy też reformę papieża Benedykta XIV - „wielkiego kanonisty” - który w roku 1741 ustanowił urząd obrońcy węzła małżeńskiego oraz wprowadził obowiązek drugiego wyroku pozytywnego w celu zawarcia nowego małżeństwa w Kościele. Dzisiejszą reformą - jak już wiemy - obowiązek ten został uchylony. Stąd też z historycznego punktu widzenia możemy powiedzieć, że jesteśmy w procesie ciągłych zmian, które dokonują się dla dobra dusz ludzkich.

Wszyscy pragniemy, aby temu najważniejszemu prawu w Kościele - zob. KPK, kan. 1752 - służyła także komentowana reforma kanonów dotyczących spraw o orzeczenie nieważności małżeństwa dokonana przez papieża Franciszka. 